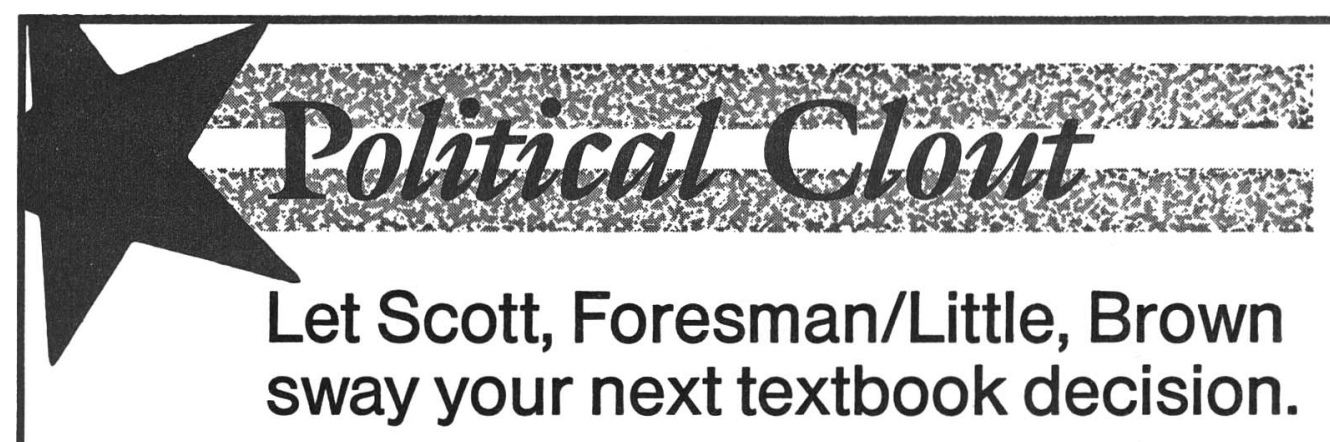

Government in America, 4/e

Lineberry / Edwards

America's Government

Harris / Wasserman

American Politics and

Government

Hinckley / Goldman

American Govern-

ment, 10/e

Woll

Politics in the American

States, 5/e

Gray / Jacob / Albritton

California Government and Politics Today, 5/e

Sohner / Field

Constitutional Law, 2/e

Feeley / Krislov

Researching Constitutional Law

Melone

Public Administration

Levine / Peters / Thompson

Making American

Economic Policy

Whicker

War, Peace, and

International Politics, 5/e

Ziegler

Foreign Policy Without

Illusion

Wiarda

Readings in United States

Foreign Policy

Wiarda

Politics in the Middle

East, 3/e

Bill / Springborg

Implementation Theory and Practice

Goggin / Bowman / Lester / O'Toole

\title{
Administrative Law and
}

Politics, 2/e

Carter / Harrington

For further information write

Meredith Hellestrae, Department SA-APSR

1900 East Lake Avenue Glenview, Illinois 60025

\section{Scott, Foresman/Little, Brown}

